\title{
The non-canonical NF- $\kappa$ B pathway is induced by cytokines in pancreatic beta cells and contributes to cell death and proinflammatory responses in vitro
}

\author{
Kira Meyerovich $^{1}$ - Makiko Fukaya ${ }^{1}$ - Leticia F. Terra ${ }^{2}$ - Fernanda Ortis ${ }^{3}$. \\ Decio L. Eizirik ${ }^{1} \cdot$ Alessandra K. Cardozo $^{1}$
}

Received: 24 July 2015 / Accepted: 29 October 2015 / Published online: 3 December 2015

(C) Springer-Verlag Berlin Heidelberg 2015

\begin{abstract}
Aims/hypothesis Activation of the transcription factor nuclear factor (NF)- $\mathrm{KB}$ by proinflammatory cytokines plays an important role in beta cell demise in type 1 diabetes. Two main signalling pathways are known to activate NF- $\mathrm{KB}$, namely the canonical and the non-canonical pathways. Up to now, studies on the role of NF-KB activation in beta cells have focused on the canonical pathway. The aim of this study was to investigate whether cytokines activate the non-canonical pathway in beta cells, how this pathway is regulated and the consequences of its activation on beta cell fate.

Methods NF-kB signalling was analysed by immunoblotting, promoter reporter assays and real-time RT-PCR, after knockdown or overexpression of key genes/proteins. INS-1E cells, FACS-purified rat beta cells and the human beta cell line EndoC- $\beta \mathrm{H} 1$ exposed to cytokines were used as models.

Results IL-1 $\beta$ plus IFN- $\gamma$ induced stabilisation of NF-KBinducing kinase and increased the expression and cleavage of p100 protein, culminating in the nuclear translocation of $\mathrm{p} 52$, the hallmark of the non-canonical signalling. This activation relied on different crosstalks between the canonical and non-canonical pathways, some of which were beta cell
\end{abstract}

Electronic supplementary material The online version of this article (doi:10.1007/s00125-015-3817-z) contains peer-reviewed but unedited supplementary material, which is available to authorised users.

Alessandra K. Cardozo

akupperc@ulb.ac.be

1 ULB Center for Diabetes Research, Université Libre de Bruxelles, Route de Lennik, 808, CP 618, 1070, Brussels, Belgium

2 Institute of Chemistry, Universidade de São Paulo, São Paulo, Brazil

3 Department of Cell and Developmental Biology, Universidade de São Paulo, São Paulo, Brazil specific. Importantly, cytokine-mediated activation of the non-canonical pathway controlled the expression of 'late' NF-KB-dependent genes, regulating both pro-apoptotic and inflammatory responses, which are implicated in beta cell loss in early type 1 diabetes.

Conclusions/interpretation The atypical activation of the non-canonical NF-kB pathway by proinflammatory cytokines constitutes a novel 'feed-forward' mechanism that contributes to the particularly pro-apoptotic effect of NF- $\mathrm{kB}$ in beta cells.

Keywords Apoptosis · Cytokines · FBW7 · FBXW7 · Inflammation · Non-canonical NF-kB pathway $\cdot$ Pancreatic beta cell $\cdot \beta \operatorname{TrCP} \cdot$ Type 1 diabetes

\begin{tabular}{|c|c|}
\hline \multicolumn{2}{|c|}{ Abbreviations } \\
\hline $\mathrm{C} / \mathrm{EBP} \delta$ & CCAAT/enhancer-binding protein- $\delta$ \\
\hline FBW7 & F-box and WD repeat domain-containing 7 \\
\hline iNOS & Inducible nitric oxide synthase \\
\hline I $\mathrm{B}$ & Inhibitor of $\kappa \mathrm{B}$ \\
\hline IKK & Inhibitor of $\mathrm{kB}$ kinase \\
\hline $\mathrm{NF}-\kappa \mathrm{B}$ & Nuclear factor- $\mathrm{kB}$ \\
\hline NIK & Nuclear factor- $\kappa \mathrm{B}$-inducing kinase \\
\hline $\mathrm{NO}$ & Nitric oxide \\
\hline siCTR & Control small interfering RNA \\
\hline siRNA & Small interfering RNA \\
\hline$\beta \operatorname{TrCP}$ & $\beta$-Transducin repeats-containing protein \\
\hline
\end{tabular}

\section{Introduction}

Type 1 diabetes is an autoimmune disease in which insulin production is compromised due to pancreatic beta cell loss [1]. This is mostly mediated by $\mathrm{T}$ cells and macrophages that invade the islets in a process called insulitis [1]. During 
insulitis, both immune cells and beta cells secrete inflammatory mediators such as chemokines, cytokines, cell adhesion molecules and nitric oxide (NO), which further activate the immune response and induce beta cell death [2, 3]. Exposure of beta cells to these proinflammatory cytokines changes gene expression, to a major extent via modulation of the transcription factor nuclear factor (NF)- $\mathrm{B}[1,2]$. Inhibition of NF- $\mathrm{kB}$ signalling in mouse beta cells in vivo protects against multiple low-dose streptozotocin-induced diabetes [4], while mice with constitutive NF- $\mathrm{KB}$ activation in beta cells spontaneously develop insulitis and immune-mediated diabetes [5]. In addition to regulating proinflammatory responses, NF- $\mathrm{kB}$ activation is also pro-apoptotic to beta cells $[1,2,6-8]$. Conversely, NF- $\mathrm{BB}$ inactivation in beta cells from NOD mice accelerates the disease [9]. This is probably related to the prolonged inhibition of the expression of NF-kB-dependent antiapoptotic proteins such as XIAP and A20 [9, 10]. Polymorphisms in the $N F K B$ gene have been identified in type 1 diabetic patients, supporting a role for this transcription factor in the pathogenesis of the human disease [11]. This is surprising, since in most other cell types NF- $\kappa$ B plays an antiapoptotic role [12].

The NF-kB family comprises the proteins p50/precursor p105, RelA, c-Rel, RelB and p52/precursor p100 [13]. While p105 and p100 are inhibitory proteins, their respective mature forms, p50 and p52, function as active transcription factors. The two major NF-kB pathways are the canonical and non-canonical pathways [13]. The canonical pathway is activated by proinflammatory agents such as cytokines, which bind to specific receptors and activate the inhibitor of $\mathrm{KB}$ (IKB) kinase (IKK) complex (IKK $\beta$, IKK $\alpha$ and NEMO) [13]. This leads to phosphorylation and degradation of the inhibitory I $\mathrm{kB}$ proteins (e.g. I $\mathrm{B} \alpha$ ), releasing NF- $\kappa \mathrm{B}$ proteins to form dimers that modify gene transcription [13].

The non-canonical pathway, which was originally associated with immune cell differentiation, maturation and survival and osteoclastogenesis [13-15], is activated via a subset of receptors from the TNF family [14]. Ligand binding activates NF-KB-inducing kinase (NIK) and the IKK $\alpha / \mathrm{IKK} \alpha$ complex, triggering phosphorylation-mediated ubiquitination of $\mathrm{p} 100$ and processing to the mature p52 subunit, which, with RelB, forms the main NF- $\mathrm{kB}$ dimer of the non-canonical pathway [14]. While the canonical pathway of NF- $\mathrm{BB}$ activation is triggered in minutes, the non-canonical signalling is slower and depends on de novo protein synthesis [14].

Up to now, all available information regarding the role and regulation of cytokine-mediated NF- $\mathrm{KB}$ activation in beta cells has focused on the canonical pathway [2, 16-18]. However, crosstalk between the canonical and non-canonical pathways might exist $[13,19]$. Therefore, the aims of this study were to investigate whether proinflammatory cytokines associated with the pathogenesis of type 1 diabetes activate the non-canonical pathway in beta cells and, if so, to examine the regulation of this pathway and the consequences of its activation on NF- $\mathrm{KB}$ proinflammatory and apoptotic responses in these cells.

\section{Methods}

Culture, treatment and transfection of FACS-purified rat beta cells, human (EndoC- $\beta$ H1) and rat (INS-1E) beta cell lines and NO measurement Three-month-old male Wistar rats (Charles River Laboratories, St Germain sur L'Arbresle, France) were housed and handled according to the Belgian Regulations for Animal Care and with permission from the local ethics committee. Pancreatic islets were isolated and primary beta cells were FACS-purified (FACSAria, BD Bioscience, San Jose, CA, USA), isolated and cultured as previously described [20]. EndoC- $\beta \mathrm{H} 1$ cells, kindly provided by R. Scharfmann (University of Paris Descartes, Paris, France) [21], were cultured as previously described [22]. INS-1E cells (provided by C. Wollheim, University of Geneva, Geneva, Switzerland) were cultured as previously described [23].

The cytokine concentrations used were [22, 23]: recombinant human IL-1 $\beta$ (R\&D Systems, Abingdon, UK) 10 U/ml for INS-1E cells and $50 \mathrm{U} / \mathrm{ml}$ for primary beta and EndoC- $\beta \mathrm{H} 1$ cells; recombinant rat IFN- $\gamma$ (R\&D Systems) $100 \mathrm{U} / \mathrm{ml}$ for INS-1E cells and $500 \mathrm{U} / \mathrm{ml}$ for primary beta cells; human IFN- $\gamma 1,000 \mathrm{U} / \mathrm{ml}$ for EndoC- $\beta \mathrm{H} 1$; recombinant murine TNF (Innogenetics, Gent, Belgium) 1,000 U/ml for all cell types. MG-132 (Sigma-Aldrich, Diegem, Belgium) was used at $1 \mu \mathrm{mol} / 1$ [24]. The small interfering (si)RNAs (30 nmol/l) used are listed in electronic supplementary material (ESM) Table 1, and transfections were performed as previously described [22, 23]. F-box and WD repeat domaincontaining 7 (FBW7) overexpression (cDNA from Addgene, Cambridge, MA, USA) was achieved by transient transfection [23]. Culture media were collected for nitrite determination (nitrite is a stable product of NO oxidation) [22].

Assessment of cell viability The percentage of viable, apoptotic and necrotic cells was determined using the DNAbinding dyes propidium iodide (PI) (5 $\mu \mathrm{g} / \mathrm{ml}$, SigmaAldrich) and Hoechst 33342 (HO) (5 $\mu \mathrm{g} / \mathrm{ml}$, SigmaAldrich). A minimum of 500 cells were counted in each experimental condition by two independent researchers, one of whom was unaware of the sample's identity [23]. In all analysed experiments, the necrotic levels were low and did not change between different conditions (data not shown).

mRNA extraction and qualitative RT-PCR Poly $(\mathrm{A})^{+}$ mRNA was isolated and reverse transcribed as previously described [23]. The real-time RT-PCR amplification reaction was performed using SYBR Green and compared with a standard curve [25]. Expression values were corrected for the 
housekeeping gene GAPDH $[2,23]$. The primers used are listed in ESM Table 1.

Immunoprecipitation Cell lysates were obtained as previously described $[8,23]$. Supernatants were precleared using protein G-Sepharose beads (GE Healthcare, Diegem, Belgium) for $1 \mathrm{~h}$ at $4^{\circ} \mathrm{C}$. Total protein $(1 \mathrm{mg} / \mathrm{ml})$ was incubated with anti-p100, anti-Myc or anti-HA antibodies overnight, followed by $2 \mathrm{~h}$ incubation with protein $\mathrm{G}$-sepharose beads at $4^{\circ} \mathrm{C}$. Beads were washed with lysis buffer, resuspended in Laemmli buffer and resolved on SDS-PAGE.

Cellular fractionation and western blot analysis Nuclear and cytoplasmic extracts from cells were obtained as previously described [16]. For total cellular extracts, cells were washed with cold PBS and lysed in Laemmli buffer. Western blot analysis was performed as previously described [23]. The antibodies used are listed in ESM Table 2. Images were acquired using ChemiDoc (Bio-Rad, Temse, Belgium) and analysed using ImageJ 1.49 software (http://imagej.nih.gov/ ij/) [26]. Protein expression was corrected by expression of the loading control proteins $\alpha$-tubulin, GAPDH or fibrillarin.

NF- $K B$ reporter assay Cells were cotransfected with the internal control pRL-CMV encoding Renilla luciferase (Promega, Madison, WI, USA) and the pNF-kB-luciferase construct (BD Bioscience), together with the control siRNA (siCTR) or specific siRNAs against NFKB2, FBW7 and/or $\beta$-transducin repeats-containing protein $(\beta \operatorname{TrCP})$. Sample preparation and measurement of luciferase activity were performed as previously described [23].

Statistical analysis Western blot and RT-PCR were corrected for the loading controls or housekeeping genes, respectively, and were normalised by the highest value in each experiment. Data are presented as means \pm SEM. Comparisons were performed using a two-tailed paired Student's $t$ test or by ANOVA followed by a paired $t$ test with Bonferroni correction for multiple comparisons. $p<0.05$ was considered statistically significant.

\section{Results}

The non-canonical NF- $\kappa B$ pathway is activated by IL-1 $\beta$ plus IFN- $\gamma$ and plays a role in beta cell apoptosis To verify whether IL-1 $\beta$ plus IFN- $\gamma$ induce the non-canonical NF- $\mathrm{KB}$ pathway in beta cells, we analysed time-related changes in p100 expression and p52 nuclear translocation in INS-1E cells. Protein levels of p100 increased in the cytoplasm after $4 \mathrm{~h}$ cytokine treatment and remained elevated for up to $24 \mathrm{~h}$ (Fig. 1a). p100 is primarily cytoplasmic [27], but after $4 \mathrm{~h}$ of cytokine treatment it accumulated in the nucleus, indicating shuttling between the two compartments (Fig. 1a). Elevated levels of p100 resulted in increased p52 generation and its progressive nuclear translocation, with a peak at $24 \mathrm{~h}$ (Fig. 1a,b). Similar results were observed with IL-1 $\beta$ or TNF alone; TNF is another cytokine involved in NF- $\mathrm{KB}$ activation and beta cell dysfunction in type 1 diabetes (ESM Fig. $1 \mathrm{a}, \mathrm{b})$. IL-1 $\beta$ plus IFN- $\gamma$ treatment also increased NIK protein expression by 3.5 -fold (Fig. 1c,d).

NFkB2 knockdown with two specific siRNAs resulted in a $50 \%$ decrease in NF- $\mathrm{KB}$ activity after IL- $1 \beta$ plus IFN- $\gamma$ treatment in INS-1E cells (Fig. 1e and ESM Fig. 1c-e). Since both siRNAs provided similar results, most subsequent experiments were performed using Nfkb2\#1 siRNA. Knockdown of NFKB2 in primary beta cells also resulted in a significant decrease of NF- $k B$ activity after IL- $1 \beta$ plus IFN- $\gamma$ exposure (Fig. 1f). Inhibition of NFKB2 protected INS-1E cells and primary beta cells from cytokine-mediated apoptosis (Fig. 1g,h). Silencing of NFKB2 in INS-1E cells affected neither the expression of $N f k b 1$ (ESM Fig. 1f) nor the cytokine-mediated degradation of I $\mathrm{KB} \alpha$ (ESM Fig. 1g-i), confirming the specificity of the siRNAs used in this study for the non-canonical NF-kB pathway.

The non-canonical NF- $\kappa B$ pathway regulates the expression of 'late' NF-KB-dependent genes Since we observed that the non-canonical NF-KB pathway is a relatively late response (starting at $4 \mathrm{~h}$ [Fig. 1a,b], as compared with $10 \mathrm{~min}$ for the canonical pathway [16]), we tested whether this pathway regulates the expression of 'late' NF- $\mathrm{kB}$-targeted genes. NFKB2 silencing (Fig. 2a) did not alter the expression of 'early' genes (induced $2 \mathrm{~h}$ after cytokine exposure), such as $A 20$ (also known as Tnfaip3), Ikba (also known as Nfkbia), Mnsod and Cxcll (also known as Grol) (Fig. 2b-e), while NFkB2 knockdown drastically decreased the mRNA expression of the 'late' genes (induced from $4 \mathrm{~h}$ onwards) $\mathrm{Ccl}$, Ccl19, Fas, Cxcl12 and Inos (also known as Nos2) (Fig. 2f-j). This was accompanied by a significant decrease in NO production (Fig. 21). Ccl2 mRNA expression was strongly induced after $8 \mathrm{~h}$ of treatment, but was not different in NFKB2-silenced cells compared with siCTR-transfected cells (Fig. 2k).

FBW7 regulates NF- $K B$ signalling in beta cells It has been previously reported that the E3-ligase FBW7 regulates the NF-KB pathway in cancer cells [28-30]. We observed that IL-1 $\beta$ plus IFN- $\gamma$ decreased $F b w 7$ (also known as $F b x w 7$ ) mRNA expression in INS-1E, rat primary beta cells and EndoC- $\beta \mathrm{H} 1$ cells $($ Fig. $3 \mathrm{a}-\mathrm{c}$ ). The transcription factor CCAAT/enhancer-binding protein- $\delta(\mathrm{C} / \mathrm{EBP} \delta)$ directly inhibits FBW7 expression in murine cancerous cells [31]. We observed that the IL- $1 \beta$ plus IFN- $\gamma$-mediated decrease in $F b w 7$ expression in INS-1E cells correlated with an increase in Cebpd gene expression (ESM Fig. 2a,b). C/EBP $\delta$ knockdown prevented cytokine-mediated $\mathrm{Fbw} 7$ downregulation (Fig. 3d), suggesting a direct link between induction of C/EBPS and downregulation of FBW7. 

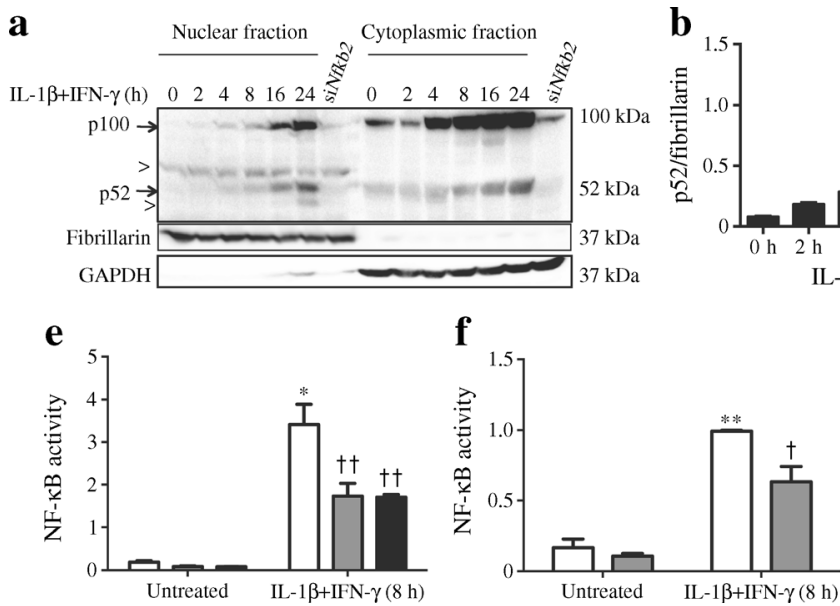

Fig. 1 Proinflammatory cytokines induce the non-canonical NF- $\kappa B$ signalling pathway in beta cells. (a, b) p100 and p52 expression in the nuclear and cytoplasmic fractions of INS-1E cells treated with IL- $1 \beta$ plus IFN- $\gamma$. INS-1E cells transfected with $N f k b 2$ siRNA and treated with IL$1 \beta$ plus IFN- $\gamma$ for $16 \mathrm{~h}$ were used as western blot controls. A representative western blot (a); arrowheads show non-specific bands; densitometric assessment of nuclear p52 (b). (c, d) Western blot analysis of NIK expression in INS-1E cells treated (black bar) or not (white bar) with IL$1 \beta$ plus IFN- $\gamma$. A representative western blot (c); densitometric assessment (d). (b, d) $* p<0.05, * * p<0.01,{ }^{* * *} p<0.001$ vs the untreated $(0 \mathrm{~h})$

A pronounced increase in NF- $k B$ activity was observed in FBW7-depleted cells after IL- $1 \beta$ plus IFN- $\gamma$ exposure (Fig. 3e-g and ESM Fig. 2b-e). The potentiation of NF- $\mathrm{kB}$ activation was also observed in FBW7-silenced INS-1E cells treated with IL-1 $\beta$ or TNF alone, indicating that this regulation is independent of IFN- $\gamma$ (Fig. 3h). In line with these results, FBW7 overexpression decreased IL-1 $\beta$ plus IFN- $\gamma$-mediated NF- $\mathrm{KB}$ activation (Fig. 3i).

FBW7 modulates p100 protein levels and consequently p52/NF- $\kappa$ B activity In tumour cells, FBW7 regulates the non-canonical NF- $\mathrm{kB}$ pathway by targeting $\mathrm{p} 100$ for degradation [28-30]. Analysis of cytoplasmic fractions from FBW7depleted cells revealed higher levels of the inhibitory protein p100 upon IL-1 $\beta$ plus IFN- $\gamma$ treatment (Fig. 4a,b). p100 accumulation resulted in increased levels of $\mathrm{p} 52$ protein in the nucleus (Fig. 4a,c). Double knockdown of FBW7 and NFkB2 prevented the potentiating effect on NF-KB activation induced by cytokines after FBW7 depletion (Fig. 4d and ESM Fig. 2f,g).

Processing of p100 to p52 may be mediated by another E3 ligase, $\beta \operatorname{TrCP}[14]$. FBW7 silencing significantly increased NF-KB activity, which was inhibited by concomitant knockdown of FBW7 and $\beta$ TrCP (Fig. 4e, ESM Fig. 3). These experiments suggest a role for $\beta \operatorname{TrCP}$ in $\mathrm{p} 100$ processing in beta cells, and support the hypothesis that the potentiating effects of FBW7 depletion on NF-KB are mediated via the cleavage of p100 to p52 and its translocation to the nucleus. Indeed, a direct interaction between FBW7 and p100 was observed in co-immunoprecipitation experiments (Fig. 4f,g). c

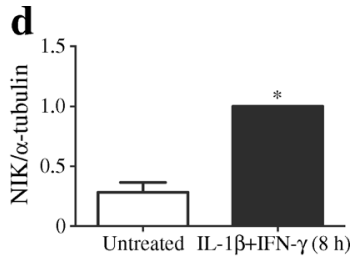

h
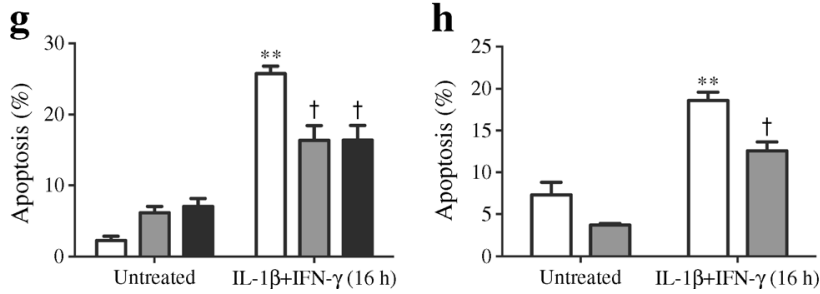

condition. (e, f) INS-1E (e) and primary beta cells (f) were transfected with NF-kB reporter and control constructs, together with siCTR (white bars), $N f k b 2$ siRNA (\#1, grey bars; \#2 black bars) and exposed to IL-1 $\beta$ plus IFN- $\gamma$. NF- $\mathrm{kB}$ activity is given as firefly/renilla ratio. (g, h) INS-1E (g) and primary beta cells (h) were transfected with siCTR (white bars), Nfkb2 siRNA (\#1, grey bars; \#2 black bars) and treated with IL-1 $\beta$ plus IFN- $\gamma$. Cell viability was assessed using Hoechst/propidium iodide $(\mathrm{HO} /$ PI) staining. (e-h) $* p<0.05, * * p<0.01$ vs the siCTR-untreated condition; ${ }^{\dagger} p<0.05,{ }^{\dagger \dagger} p<0.01$ vs the respective siCTR-transfected condition. Results are means \pm SEM of three or four independent experiments

FBW7 depletion, however, did not change IL- $1 \beta$ plus IFN- $\gamma$ induced I $\mathrm{K} B \alpha$ degradation (ESM Fig. 2h,i), excluding regulation of the canonical pathway.

Expression of the 'early' genes $A 20$ and Ikba after FBW7 knockdown (Fig. 5a) was comparable in both transfected groups (Fig. 5b,c), while expression of the 'late' genes $\mathrm{Ccl}$, Ccl19, Fas, Cxcl12 and Inos increased (Fig. 5d-h). Moreover, FBW7 silencing enhanced NO production (Fig. 5j). As observed in NFKB2-silenced cells, Ccl2 expression was not modified between the transfection conditions (Fig. 5i). Overall, the observed effects of FBW7 silencing were opposite to those of NFKB2 silencing (Fig. 2), confirming that FBW7 hampers non-canonical NF-KB responses.

FBW7 knockdown increases cytokine-induced beta cell apoptosis FBW7-silenced INS-1E, EndoC- $\beta \mathrm{H} 1$, and primary beta cells were sensitised to IL- $1 \beta$ plus IFN- $\gamma$-induced apoptosis (Fig. 6a-c). Double knockdown of FBW7 and NFKB2 or FBW7 and $\beta \operatorname{TrCP}$ partially protected against FBW7knockdown mediated apoptosis (Fig. 6d,e), suggesting that the increased beta cell death after FBW7 depletion is at least partly due to activation of the non-canonical NF- $\mathrm{KB}$ pathway.

\section{Discussion}

NF- $\mathrm{KB}$ controls the expression of genes regulating cell survival, development, differentiation and metabolism, and is crucial for immune responses $[13,14]$. In the context of type 1 
Fig. 2 The non-canonical NF- $k B$ pathway regulates the expression of 'late' NF-kB dependent genes in beta cells. (a-k) INS-1E cells were transfected with siCTR (solid line) or Nfkb2\#1 siRNA (dashed line) and treated with IL$1 \beta$ plus IFN- $\gamma$. mRNA expression of $N f k b 2$ (a), $A 20$ (b), Ikba (c), Mnsod (d), Cxcll (e), Ccl5 (f), Ccl19 (g), Fas (h), Cxcl12 (i), Inos (j) and Ccl2 (k). (l) Nitrite accumulation in the culture medium. ${ }^{*} p<0.05$, ${ }^{* *} p<0.01,{ }^{* * *} p<0.001$ vs the siCTR-untreated $(0 \mathrm{~h})$ condition; ${ }^{\dagger} p<0.05,{ }^{\dagger \dagger} p<0.01,{ }^{\dagger \dagger} p<0.001$ vs the respective siCTRtransfected condition. Results are means \pm SEM of six independent experiments
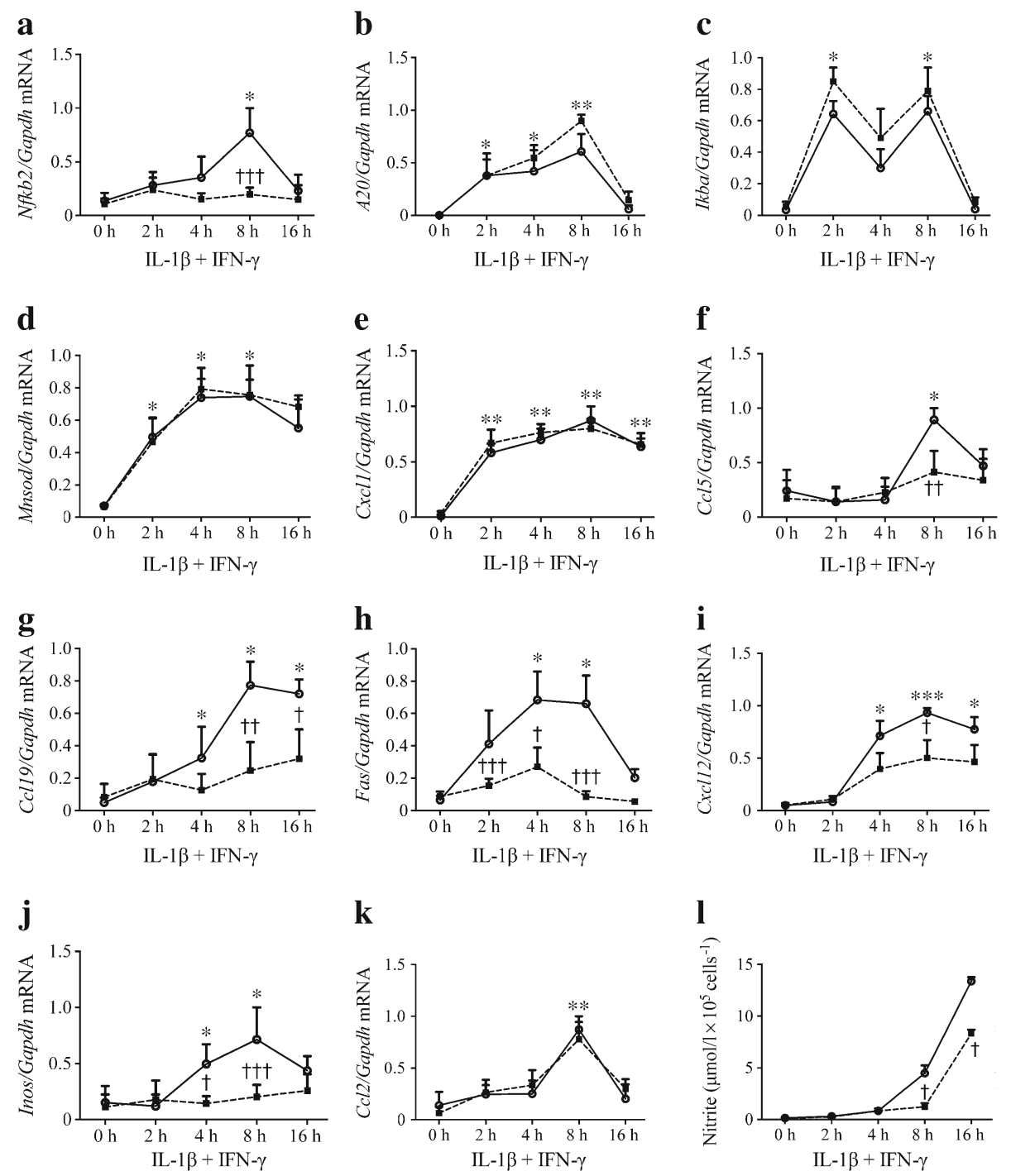

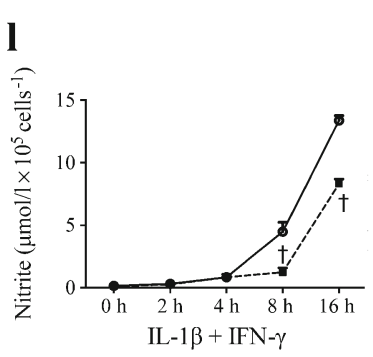

diabetes, beta cell-mediated NF- $\mathrm{kB}$ activation contributes to its own demise $[1,4,5,7]$. The proinflammatory role of $\mathrm{NF}-\mathrm{KB}$ is similar in beta cells and other cell types, but the transcription factor is unusually pro-apoptotic in beta cells $[7,8,12]$. The reasons for this susceptibility of beta cells to NF-KB have remained a puzzle in the field. In the present study, we found that non-canonical signalling is atypically activated by IL-1 $\beta$ (alone or in combination with IFN- $\gamma$ ) or $\mathrm{TNF}$, regulating late NF-KB-mediated pro-apoptotic and proinflammatory responses in beta cells, which may provide an explanation for the predominantly pro-apoptotic effects of the transcription factor in beta cells.

Ligands such as receptor activator of NF-KB (RANK) and membrane-bound, but non-soluble TNF have been shown to activate the non-canonical NF-KB pathway $[15,32]$, while proinflammatory cytokines such as IL- $1 \beta$ and soluble TNF are considered to preferentially activate the canonical NF- $\mathrm{KB}$ pathway [7, 8, 17]. By using an siRNA targeting $N f k b 2$, we observed that both IL-1 $\beta$ (alone or in combination with
IFN- $\gamma$ ) and soluble TNF activated the non-canonical NF-kB pathway in pancreatic beta cells. These findings are intriguing and have not been previously described in other cell types. The $N f k b 2$ siRNAs used in this study were specific and did not interfere with the canonical NF-kB pathway, as judged by their lack of effect on the expression of $N f k b 1$ or I $\mathrm{I} \mathrm{B} \alpha$ degradation in response to IL-1 $\beta$ plus IFN- $\gamma$. In line with our findings, Malle et al showed that soluble TNF induces the processing of p100 to p52 in mouse islets, while Wolden-Kirk et al observed $\mathrm{p} 52$ activation in mouse islets exposed to IL- $1 \beta$ plus IFN- $\gamma[33,34]$.

The canonical and non-canonical NF- $\mathrm{kB}$ pathways were initially believed to fulfil different functions, but recent studies have revealed crosstalk between them [13, 19]. Thus, the increase in NFKB2 expression by the canonical pathway positively regulates the non-canonical pathway by providing a greater amount of precursor $\mathrm{p} 100$ for $\mathrm{p} 52$ generation [35]. Accordingly, exposure to IL-1 $\beta$ (alone or in combination with IFN- $\gamma$ ) or TNF increased the expression of both $N f k b 2$ 

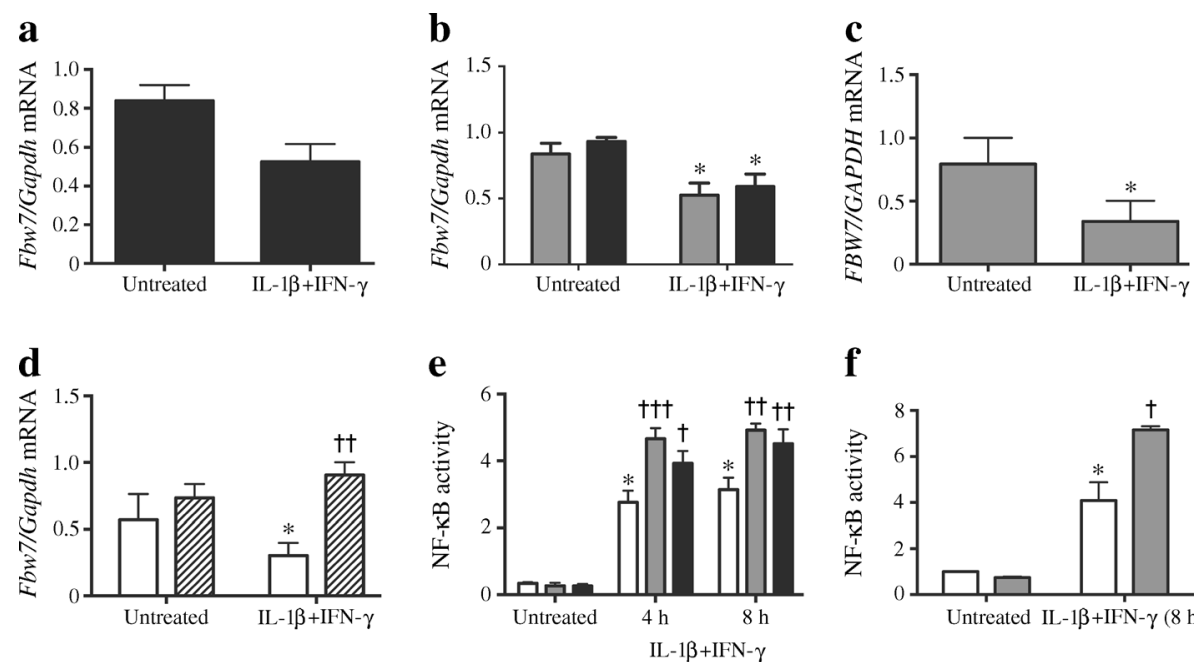

$\mathbf{f}$
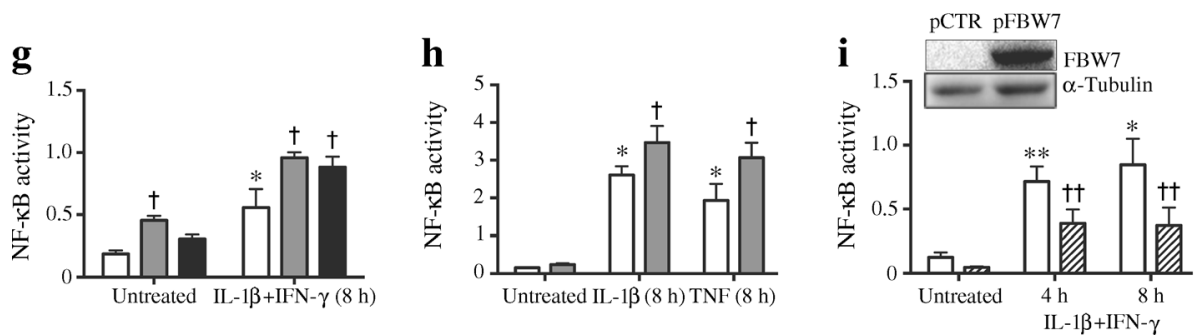

Fig. 3 FBW7 knockdown potentiates cytokine-induced NF-kB activation in beta cells. (a-c) $F B W 7$ mRNA expression in INS-1E (a), primary rat beta cells (b) or EndoC- $\beta$ H1 cells (c) after IL- $1 \beta$ plus IFN- $\gamma$ treatment ( $16 \mathrm{~h}$, black bars; $24 \mathrm{~h}$, grey bars). ${ }^{*} p<0.05$ vs the untreated condition. (d) INS-1E cells were transfected with siCTR (white bars) or Cebpd siRNA (hatched bars) and exposed to IL- $1 \beta$ plus IFN- $\gamma$. mRNA expression of $F b w 7$ was analysed. INS-1E (e, h), primary rat beta (f) and EndoC- $\beta \mathrm{H} 1$ cells (g) were transfected with NF-KB reporter and a control construct, together with siCTR (white bars), FBW7 siRNAs (\#1, grey bars; \#2, black

mRNA and p100 protein in INS-1E cells. A central signalling element is the activation/stabilisation of NIK [14]. We observed low NIK protein levels in resting cells, which increased several-fold upon cytokine treatment.

The IKK complex containing NEMO and IKK $\beta$ plays an important role in the maintenance of the low basal levels of NIK, thus suppressing basal non-canonical NF- $\mathrm{KB}$ signalling [19]. IL- $1 \beta$ mediates IKK $\beta$ degradation in beta cells, leading to IKK $\alpha$ homodimer activation [8]. It is thus conceivable that an IL- $1 \beta$-mediated decrease in IKK $\beta$ in beta cells contributes to increased NIK protein levels. Stabilised NIK phosphorylates/activates IKK $\alpha$, resulting in p100 processing and non-canonical NF- $\mathrm{KB}$ activation [14]. We suggest that an IL- $1 \beta$ plus IFN- $\gamma$-mediated increase in IKK $\alpha$ complexes [8], together with increased expression of NIK and p100, contributes to the activation of the non-canonical pathway in beta cells (ESM Fig. 4). This stabilising effect of IL- $1 \beta$ plus IFN- $\gamma$ on NIK protein has not previously been described in other cells types, but overexpression of mutant NIK protein has been reported to inhibit IL- $1 \beta$-mediated NF- $\mathrm{B}$ activation in bars) and treated with cytokines. (i) INS-1E cells were transfected with $\mathrm{NF}-\mathrm{KB}$ reporter and a control construct, together with an empty plasmid (pCTR, white bars) or a plasmid encoding FBW7 (pFBW7, hatched bars) and treated with IL- $1 \beta$ plus IFN- $\gamma$. NF-kB activity is shown with a representative western blot for FBW7 in pCTR- and pFBW7-transfected cells. (e-i) NF- $\mathrm{kB}$ activity is given as firefly/renilla ratio. $(\mathbf{d}-\mathbf{i}) * p<0.05$, ${ }^{*} p<<0.01$ vs the siCTR-untreated condition; ${ }^{\dagger} p<0.05,{ }^{\dagger \dagger} p<0.01$, ${ }^{\dagger \dagger} p<0.001$ vs the respective siCTR-transfected condition. Results are means \pm SEM of three to five independent experiments

293 EBNA cells [36], indicating the impact of NIK in cytokine-mediated NF- $\mathrm{KB}$ activation in these cells.

NF- $K B$ activation occurs in distinct waves, triggering the expression of 'early' and 'late' genes [16, 37]. The general pattern of NF- $\mathrm{KB}$ activation in beta cells is not oscillatory, but sustained [16]. Based on the present results, we propose that the non-canonical pathway contributes to the 'late' response. Accordingly, NFkB2 silencing hampers the induction of 'late' NF- $\kappa \mathrm{B}$ genes without affecting the expression of 'early' genes. Inducible NO synthase (iNOS) and Fas, important regulators of beta cell apoptosis, are regulated by the noncanonical NF-KB pathway [1, 6, 38]. Although Fas upregulation is mostly related to cell death in vivo [39, 40], decreased iNOS expression and NO production could contribute to the decreased apoptosis in NFKB2-silenced cells [1, 6, 38]. Importantly, the non-canonical pathway enhances the expression of the chemokines $C c l 5, C c l 19$ and $C x c l 12$. CCL5 levels are elevated in serum of type 1 diabetic patients and contribute to the attraction of monocytes and neutrophils to the islets during insulitis [41, 42]. CCL19 levels are also increased 

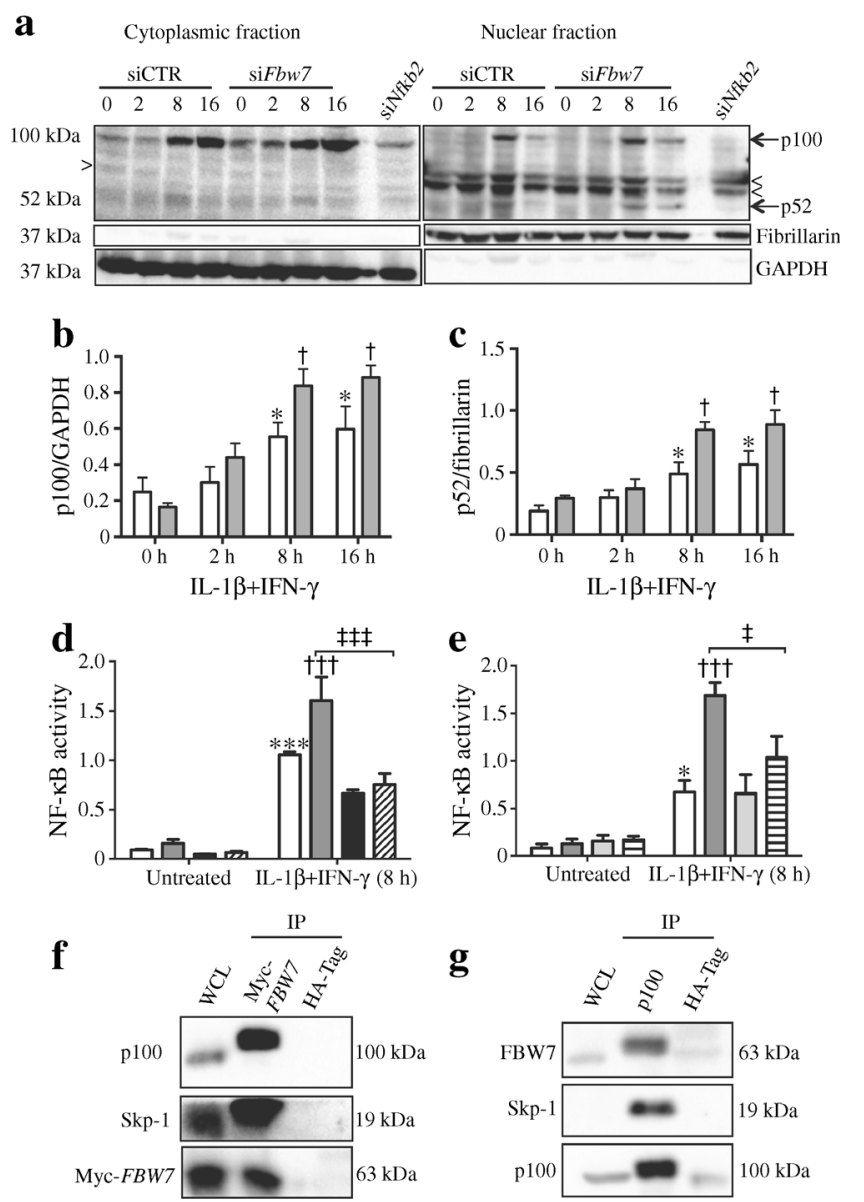

Fig. 4 FBW7 regulates the non-canonical NF- $\mathrm{kB}$ pathway in beta cells. (a-c) INS-1E cells were transfected with siCTR (white bars) or Fbw7\#1 siRNA (grey bars) and exposed to IL- $1 \beta$ plus IFN- $\gamma$. Expression of p100 and $\mathrm{p} 52$ was analysed in nuclear and cytoplasmic fractions. INS-1E cells transfected with $N f k b 2$ siRNA and treated with IL- $1 \beta$ plus IFN- $\gamma$ for $16 \mathrm{~h}$ were used as used as western blot controls. A representative western blot (a); arrowheads show non-specific bands; densitometric assessments of cytoplasmic p100 (b) and nuclear p52 (c). (d, e) INS-1E cells were transfected with an NF- $\mathrm{kB}$ reporter and a control construct, together with siCTR (white bars) and Fbw7\#1 (dark grey bars), Nfkb2\#1 (black bars), Nfkb2\#1 and Fbw7\#1 (hatched bars), Btrcp\#1 (light grey bars), or Btrcp\#1 and Fbw7\#1 (horizontal striped bars) siRNA and treated with IL-1 $\beta$ plus IFN- $\gamma$. NF- $k B$ activity is given as firefly/renilla ratio. (b-e) ${ }^{*} p<0.05,{ }^{* *} p<0.001$ vs the siCTR-untreated $(0 \mathrm{~h})$ condition; ${ }^{\dagger} p<0.05$, ${ }^{+\dagger} p<0.001$ vs the respective siCTR-transfected condition; ${ }^{\star} p<0.05$, 柆 $p<0.001$ vs the respective Fbw7\#1 siRNA-transfected condition. Results are means \pm SEM of three or four independent experiments. (f) INS$1 \mathrm{E}$ cells were transfected with a plasmid encoding tagged $F B W 7 \mathrm{cDNA}$ (Myc-FBW7). After $72 \mathrm{~h}$, the cells were lysed and immunoprecipitated with Myc-Tag or HA-Tag (negative control) antibodies and immunoblotted for $\mathrm{p} 100$ and Skp-1 (positive control, a subunit of a complex containing FBW7 and Cullin-1 [50]). (g) INS-1E cells were lysed and immunoprecipitated with p100 or HA-Tag antibodies and immunoblotted for FBW7 and Skp-1. A representative western blot of three independent experiments is shown

during diabetes development and enhance the migration of dendritic cells and macrophages to the islets [43, 44]. CXCL12 levels are elevated in type 1 diabetes, and CXCL12 contributes to insulitis by stimulating the trafficking and homing of autoreactive $\mathrm{B}$ and T cells in animal models of type 1 diabetes $[45,46]$. CCL19 and CXCL12 genes have been reported to be downstream of the non-canonical NF- $\mathrm{KB}$ pathway in other cell types [47, 48]. Although CCL2 is a 'late' gene, its expression was not modulated in NFKB2-silenced cells, supporting the hypothesis that both time and the type of dimer are important for NF- $\mathrm{KB}$ regulation [49].

The E3 ligase FBW7 promotes p100 degradation in tumour cells, and FBW7 deficiency reduces NF- $\mathrm{KB}$ activation due to accumulation of this inhibitory protein [28-30]. In this study, we confirmed the FBW7-p100 interaction and increased p100 protein levels in response to FBW7 depletion in INS-1E cells. However, in contrast to the effects reported in tumour cells, FBW7 knockdown potentiated cytokine-mediated NF- $\mathrm{KB}$ activation, while its overexpression reduced this activity in beta cells. This might be due to the processing of accumulated p100 to p52 by the E3 ligase $\beta \operatorname{TrCP}$, since p52 levels were increased in the nuclear fractions of FBW7-silenced INS-1E cells and concomitant knockdown of FBW7 and $\beta \operatorname{TrCP}$ reversed the effects of FBW7 on NF-kB activation. Fukushima et al reported decreased protein and gene expression of the canonical NF-KB targets NFKBI and IKBA in FBW7-knockout cells, suggesting a role for FBW7 in canonical signalling [30]. Our results argue against a similar mechanism in beta cells, since the increased activation of the NF-KB reporter gene (which can be induced by both pathways) observed in FBW7-silenced beta cells was abolished in cells silenced for FBW7 and NFkB2. Moreover, FBW7 knockdown did not alter $I k b a$ mRNA expression or its cytokine-induced protein degradation. Finally, FBW7 deficiency modified the expression pattern only of NF- $\mathrm{KB}$ 'late' genes, regulated by the non-canonical pathway, but not of the 'early' genes (probably induced by the canonical pathway). Overall, these findings support a specific role for FBW7 in regulating the non-canonical NF- $\mathrm{kB}$ pathway in beta cells. We observed that proinflammatory cytokines induced Btrcp (also known as Btrc) gene expression [23] and upregulated Cebpd, leading to decreased $F b w 7$ expression. These events contribute to the activation of the non-canonical pathway by preventing p100 degradation, and therefore constitute another level of regulation of this pathway in beta cells (ESM Fig. 4). FBW7 knockdown exacerbated cytokine-mediated apoptosis, which was partially reversed by simultaneous silencing of FBW7 and NFkB2 or $\beta$ TrCP. These data support a proapoptotic role for the non-canonical NF-KB pathway in beta cells.

We conclude that induction of the canonical pathway by IL- $1 \beta$ plus IFN- $\gamma$ triggers a cascade of events, leading to atypical activation of the non-canonical pathway. Beta cellspecific steps in this pathway include: (1) activation of the non-canonical pathway by IL- $1 \beta$ plus IFN- $\gamma$; (2) upregulation/stabilisation of NIK expression by these cytokines; (3) a stimulatory effect of FBW7 knockdown on 
a

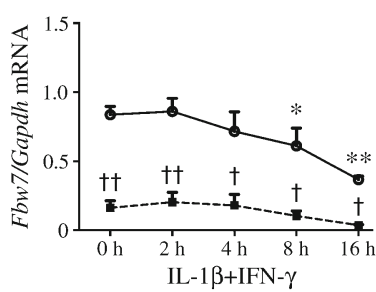

e

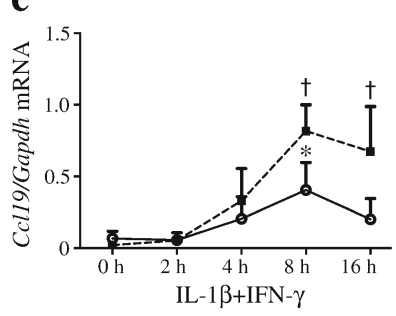

f

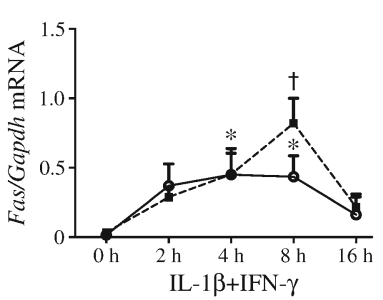

i

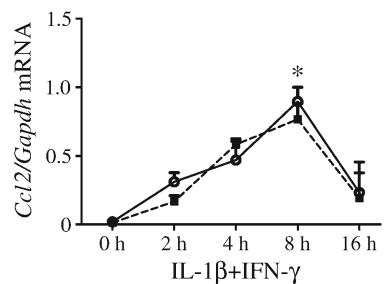

Fig. 5 FBW7-knockdown increases mRNA expression of 'late' NF-kB target genes and NO production. $(\mathbf{a}-\mathbf{i})$ INS-1E cells were transfected with siCTR (solid line) or $F b w 7 \# 1$ siRNA (dashed line) and treated with IL-1 $\beta$ plus IFN- $\gamma$. mRNA expression of $F b w 7$ (a), $A 20$ (b), Ikba (c), Ccl5 (d), Ccl19 (e), Fas (f), Cxcl12 (g), Inos (h) and Ccl2 (i). (j) Nitrite

NF- $\mathrm{KB}$ activation; and (4) downregulation of IKK $\beta$ by IL-1 $\beta$ [8]. These events constitute a novel 'feed-forward' c

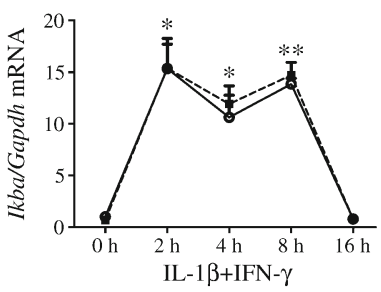

g

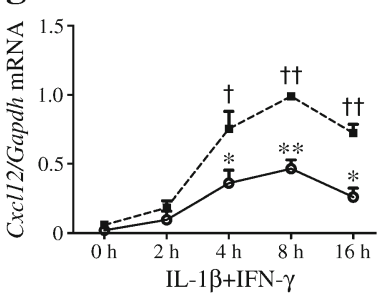

j

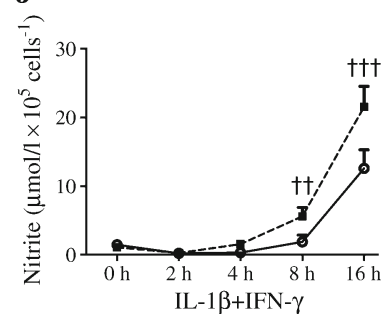

accumulation in the culture medium. ${ }^{*} p<0.05, * * p<0.01, * * * p<0.001$ vs the siCTR-untreated $(0 \mathrm{~h})$ condition; ${ }^{\dagger} p<0.05,{ }^{\dagger} p<0.01,{ }^{\dagger \dagger} p<0.001$ vs the respective siCTR-transfected condition. Results are means \pm SEM of six independent experiments

mechanism that might contribute to the particularly proapoptotic effect of NF-KB in beta cells (ESM Fig. 4). d
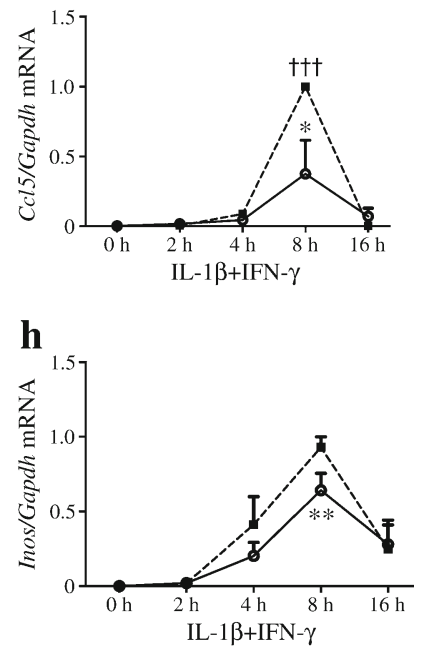

a

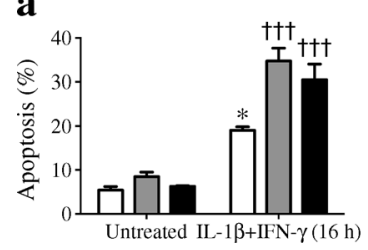

d

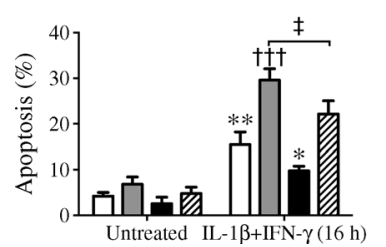

b

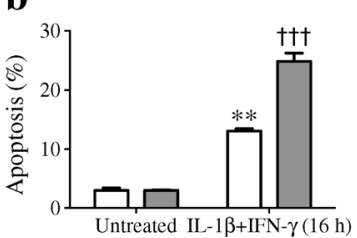

$\mathbf{e}$

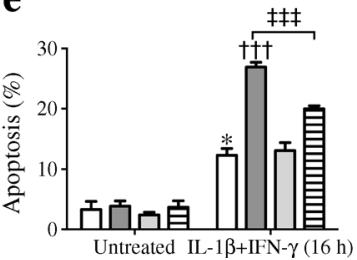

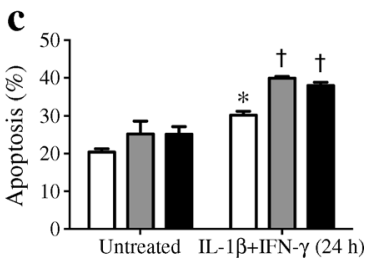

(light grey bar), or Btrcp\#1 and $F b w 7 \# 1$ (horizontal-lined bar) siRNA and treated with IL- $1 \beta$ plus IFN- $\gamma$. (a-e) $* p<0.05$, $* * p<0.01$ vs the siCTRuntreated condition; ${ }^{\dagger} p<0.05,{ }^{\dagger \dagger} p<0.001$ vs the respective siCTRtransfected condition; ${ }^{\star} p<0.05,{ }^{+\star} p<0.001$ vs the FBW7\#1 siRNAtransfected condition. Data are means \pm SEM of three to six independent experiments 
Acknowledgements We thank I. Millard, A. Musuaya, S. Mertens and M. Pangerl (ULB Center for Diabetes Research, Brussels, Belgium) for expert technical assistance. EndoC- $\beta \mathrm{H} 1$ cells were kindly provided by $\mathrm{R}$. Scharfmann (University of Paris, Paris, France). We are grateful to the Flow Cytometry Facility of the Erasmus Campus of the ULB and Christine Dubois for cell sorting.

Funding Work in the group led by AKC is supported by the JDRF (New York, USA; 1-2011-589), Actions de Recherché Concertées de la Communauté Française (ARC, Belgium; 20063) and National Funds from Scientific Research (FNRS, Belgium; F.4521.11). LFT received a fellowship from Coordenação de Aperfeiçoamento de Pessoal de Nivel Superior $(5134 / 11-0)$. The research of FO is financed by Fundação de Auxilio a Pesquisa do Estado de São Paulo (2010/05587-1). The research of DLE was supported by the FNRS (T.0036.13), ARC (20063), the European Union (Framework Programme 7 of the European Community; 277713) and the JDRF (3-SRA-2014-32-S-B). AKC was a research associate from FNRS (2006-2015).

Duality of interest The authors declare that there is no duality of interest associated with this manuscript.

Contribution statement $\mathrm{KM}, \mathrm{AKC}$, DLE and FO contributed to the conception and experimental design of the study and interpretation of the results. KM, MF, LFT and AKC carried out the experiments and/or helped with data analysis. $\mathrm{KM}$ and $\mathrm{AKC}$ wrote the manuscript. $\mathrm{KM}$ and $\mathrm{AKC}$ are responsible for the integrity of the work as a whole. All authors revised the article and approved the final version to be published.

\section{References}

1. Eizirik DL, Colli ML, Ortis F (2009) The role of inflammation in insulitis and $\beta$-cell loss in type 1 diabetes. Nat Rev Endocrinol 5: 219-226

2. Cardozo AK, Heimberg H, Heremans Y et al (2001) A comprehensive analysis of cytokine-induced and nuclear factor- $\mathrm{kB}-$ dependent genes in primary rat pancreatic $\beta$-cells. J Biol Chem 276:4887948886

3. Grieco FA, Vendrame F, Spagnuolo I, Dotta F (2011) Innate immunity and the pathogenesis of type 1 diabetes. Semin Immunopathol 33:57-66

4. Eldor R, Yeffet A, Baum K et al (2006) Conditional and specific NF- $\mathrm{kB}$ blockade protects pancreatic beta cells from diabetogenic agents. Proc Natl Acad Sci U S A 103:5072-5077

5. Salem HH, Trojanowski B, Fiedler K et al (2014) Long-term IKK2/NF-KB signaling in pancreatic $\beta$-cells induces immunemediated diabetes. Diabetes 63:960-975

6. Gurzov EN, Eizirik DL (2011) Bcl-2 proteins in diabetes: mitochondrial pathways of beta-cell death and dysfunction. Trends Cell Biol 21:424-431

7. Giannoukakis N, Rudert WA, Trucco M, Robbins PD (2000) Protection of human islets from the effects of interleukin- $1 \beta$ by adenoviral gene transfer of an IKB repressor. J Biol Chem 275: 36509-36513

8. Ortis F, Miani M, Colli ML et al (2012) Differential usage of NF-kB activating signals by IL- $1 \beta$ and TNF- $\alpha$ in pancreatic beta cells. FEBS Lett 586:984-989

9. Kim S, Millet I, Kim HS et al (2007) NF-KB prevents $\beta$ cell death and autoimmune diabetes in NOD mice. Proc Natl Acad Sci U S A 104:1913-1918
10. Liuwantara D, Elliot M, Smith MW et al (2006) Nuclear factor- $k B$ regulates $\beta$-cell death: a critical role for A20 in $\beta$-cell protection. Diabetes 55:2491-2501

11. Hegazy DM, O'Reilly DA, Yang BM, Hodgkinson AD, Millward BA, Demaine AG (2001) NFKB polymorphisms and susceptibility to type 1 diabetes. Genes Immun 2:304-308

12. Karin M, Lin A (2002) NF-kB at the crossroads of life and death. Nat Immunol 3:221-227

13. Shih VF, Tsui R, Caldwell A, Hoffmann A (2011) A single NFkB system for both canonical and non-canonical signaling. Cell Res 21: 86-102

14. Sun SC (2012) The noncanonical NF-kB pathway. Immunol Rev 246:125-140

15. Novack DV, Yin L, Hagen-Stapleton A et al (2003) The IkB function of NF-kB2 p100 controls stimulated osteoclastogenesis. J Exp Med 198:771-781

16. Ortis F, Cardozo AK, Crispim D, Storling J, Mandrup-Poulsen T, Eizirik DL (2006) Cytokine-induced proapoptotic gene expression in insulin-producing cells is related to rapid, sustained, and nonoscillatory nuclear factor- $\mathrm{KB}$ activation. Mol Endocrinol 20: 1867-1879

17. Ortis $\mathrm{F}$, Pirot $\mathrm{P}$, Naamane $\mathrm{N}$ et al (2008) Induction of nuclear factor$\kappa B$ and its downstream genes by TNF- $\alpha$ and IL- $1 \beta$ has a proapoptotic role in pancreatic beta cells. Diabetologia 51:1213-1225

18. Wang Y, Zhu Y, Gao L et al (2012) Formononetin attenuates IL-1 $\beta$ induced apoptosis and NF-kB activation in INS-1 cells. Molecules 17:10052-10064

19. Gray CM, Remouchamps C, McCorkell KA et al (2014) Noncanonical NF- $\mathrm{kB}$ signaling is limited by classical NF- $\mathrm{kB}$ activity. Sci Signal 7:ra13

20. Marroqui L, Masini M, Merino B et al (2015) Pancreatic $\alpha$ cells are resistant to metabolic stress-induced apoptosis in type 2 diabetes. EBioMed 2:378-385

21. Ravassard P, Hazhouz Y, Pechberty S et al (2011) A genetically engineered human pancreatic $\beta$ cell line exhibiting glucoseinducible insulin secretion. J Clin Invest 121:3589-3597

22. Brozzi F, Nardelli TR, Lopes M et al (2015) Cytokines induce endoplasmic reticulum stress in human, rat and mouse beta cells via different mechanisms. Diabetologia 58:2307-2316

23. Allagnat F, Fukaya M, Nogueira TC et al (2012) C/EBP homologous protein contributes to cytokine-induced pro-inflammatory responses and apoptosis in $\beta$-cells. Cell Death Differ 19:1836-1846

24. Yamamoto M, Ito T, Shimizu T et al (2010) Epigenetic alteration of the NF-KB-inducing kinase (NIK) gene is involved in enhanced NIK expression in basal-like breast cancer. Cancer Sci 101:2391-2397

25. Rasschaert J, Ladriere L, Urbain M et al (2005) Toll-like receptor 3 and STAT- 1 contribute to double-stranded RNA+ interferon- $\gamma$ induced apoptosis in primary pancreatic $\beta$-cells. J Biol Chem 280:33984-33991

26. Schneider CA, Rasband WS, Eliceiri KW (2012) NIH Image to ImageJ: 25 years of image analysis. Nat Methods 9:671-675

27. Solan NJ, Miyoshi H, Carmona EM, Bren GD, Paya CV (2002) RelB cellular regulation and transcriptional activity are regulated by p100. J Biol Chem 277:1405-1418

28. Arabi A, Ullah K, Branca RM et al (2012) Proteomic screen reveals Fbw7 as a modulator of the NF-KB pathway. Nat Commun 3:976

29. Busino L, Millman SE, Scotto L et al (2012) Fbxw7 $\alpha$ - and GSK3mediated degradation of $\mathrm{p} 100$ is a pro-survival mechanism in multiple myeloma. Nat Cell Biol 14:375-385

30. Fukushima $\mathrm{H}$, Matsumoto A, Inuzuka $\mathrm{H}$ et al (2012) $\mathrm{SCF}^{\mathrm{Fbw} 7}$ modulates the NFKB signaling pathway by targeting NFKB2 for ubiquitination and destruction. Cell Rep 1:434-443

31. Balamurugan K, Wang JM, Tsai HH et al (2010) The tumour suppressor C/EBP $\delta$ inhibits FBXW7 expression and promotes mammary tumour metastasis. EMBO J 29:4106-4117 
32. Rauert H, Wicovsky A, Muller N et al (2010) Membrane tumor necrosis factor (TNF) induces p100 processing via TNF receptor2 (TNFR2). J Biol Chem 285:7394-7404

33. Malle EK, Zammit NW, Walters SN et al (2015) Nuclear factor kBinducing kinase activation as a mechanism of pancreatic $\beta$ cell failure in obesity. J Exp Med 212:1239-1254

34. Wolden-Kirk H, Rondas D, Bugliani M et al (2014) Discovery of molecular pathways mediating 1,25-dihydroxyvitamin D3 protection against cytokine-induced inflammation and damage of human and male mouse islets of Langerhans. Endocrinology 155:736-747

35. Oeckinghaus A, Hayden MS, Ghosh S (2011) Crosstalk in NF-kB signaling pathways. Nat Immunol 12:695-708

36. Malinin NL, Boldin MP, Kovalenko AV, Wallach D (1997) MAP3K-related kinase involved in NF-KB induction by TNF, CD95 and IL-1. Nature 385:540-544

37. Tian B, Nowak DE, Brasier AR (2005) A TNF-induced gene expression program under oscillatory NF- $\mathrm{kB}$ control. BMC Genomics 6:137

38. Cardozo AK, Ortis F, Storling J et al (2005) Cytokines downregulate the sarcoendoplasmic reticulum pump $\mathrm{Ca}^{2+}$ ATPase $2 \mathrm{~b}$ and deplete endoplasmic reticulum $\mathrm{Ca}^{2+}$, leading to induction of endoplasmic reticulum stress in pancreatic $\beta$-cells. Diabetes 54:452-461

39. Moriwaki M, Itoh N, Miyagawa J et al (1999) Fas and Fas ligand expression in inflamed islets in pancreas sections of patients with recent-onset type I diabetes mellitus. Diabetologia 42:1332-1340

40. de Oliveira GL, Malmegrim KC, Ferreira AF et al (2012) Upregulation of fas and fasL pro-apoptotic genes expression in type 1 diabetes patients after autologous haematopoietic stem cell transplantation. Clin Exp Immunol 168:291-302

41. Carvalho-Pinto C, Garcia MI, Gomez L et al (2004) Leukocyte attraction through the CCR5 receptor controls progress from insulitis to diabetes in non-obese diabetic mice. Eur J Immunol 34:548-557
42. Chatzigeorgiou A, Harokopos V, Mylona-Karagianni C, Tsouvalas E, Aidinis V, Kamper EF (2010) The pattern of inflammatory/antiinflammatory cytokines and chemokines in type 1 diabetic patients over time. Ann Med 42:426-438

43. Carrero JA, Calderon B, Towfic F, Artyomov MN, Unanue ER (2013) Defining the transcriptional and cellular landscape of type 1 diabetes in the NOD mouse. PLoS One 8, e59701

44. Lee MH, Lee WH, Todorov I, Liu CP $(2010) \mathrm{CD} 4^{+} \mathrm{CD} 25^{+}$regulatory $\mathrm{T}$ cells prevent type 1 diabetes preceded by dendritic celldominant invasive insulitis by affecting chemotaxis and local invasiveness of dendritic cells. J Immunol 185:2493-2501

45. Ide A, Kawasaki E, Abiru N et al (2003) Stromal-cell derived factor-1 chemokine gene variant is associated with type 1 diabetes age at onset in Japanese population. Hum Immunol 64:973-978

46. Glawe JD, Mijalis EM, Davis WC et al (2013) SDF-1-CXCR4 differentially regulates autoimmune diabetogenic $\mathrm{T}$ cell adhesion through ROBO1-SLIT2 interactions in mice. Diabetologia 56: 2222-2230

47. Kew RR, Penzo M, Habiel DM, Marcu KB (2012) The IKK $\alpha$ dependent NF- $\mathrm{KB}$ p52/RelB noncanonical pathway is essential to sustain a CXCL12 autocrine loop in cells migrating in response to HMGB1. J Immunol 188:2380-2386

48. Ruckle A, Haasbach E, Julkunen I, Planz O, Ehrhardt C, Ludwig S (2012) The NS1 protein of influenza A virus blocks RIG-I-mediated activation of the noncanonical NF-KB pathway and p52/RelBdependent gene expression in lung epithelial cells. J Virol 86: 10211-10217

49. Saccani S, Pantano S, Natoli G (2003) Modulation of NF-kB activity by exchange of dimers. Mol Cell 11:1563-1574

50. Hao B, Oehlmann S, Sowa ME, Harper JW, Pavletich NP (2007) Structure of a Fbw7-Skp1-cyclin E complex: multisitephosphorylated substrate recognition by SCF ubiquitin ligases. Mol Cell 26:131-143 